\title{
Metody pobierania próbek do badań organizmów niszczących zabytki
}

\section{Wstęp}

$\mathrm{D}$ o konserwacji bardzo często trafiaja zabytki z objawami biodeterioracji, czyli zniszczeń dokonanych przez mikroorganizmy - grzyby pleśniowe, bakterie lub aerofilne glony - oraz organizmy wyższe - grzyby domowe, owady, porosty lub mchy. Zniszczenia te odnajduje się zarówno w obiektach na podłożach organicznych, takich jak różne gatunki papierów, skóry wyprawiane różnymi metodami, tkaniny, malowidła, ale także w obiektach na podłożach nieorganicznych - z kamienia, cegły, a nawet szkła (fot. 1, 2). Wyłaniają się wówczas pytania o żywotność organizmów, które spowodowały zniszczenia, o konieczność dezynfekcji, czasami także o identyfikację gatunków mikroorganizmów i ich uzdolnienia umożliwiające im przeprowadzanie różnych procesów składających się na biodeteriorację. Niezbędne staje się pobranie próbki do badań w tym kierunku. Tylko prawidłowo pobrana próbka jest przydatna w badaniach mikrobiologicznych ${ }^{1}$. Niekiedy powstaje konieczność pobrania próbek z żerowiska owadów lub próbek porostów i mchów z rzeźby kamiennej lub elewacji budynku. Do-

1 M.S. Favero, J. J. McDade, J. A. Robertsen, R. K. Hoffman, R. W. Edwards, Microbiological Sampling of Surfaces, "Journal of Applied Bacteriology" 31, 1968, s. 336-343; P. Hirsch, F. E.W. Eckhardt, R. J. Palmer Jr, Methods for the study of rock-inhabiting microorganisms - a mini review, "Journal of Microbiological Methods '23, 1995, s. 143-167. 
brze jest, jeśli dokonują tego wspólnie konserwator i biolog, ale nie zawsze jest to możliwe, np. z racji odległości i dodatkowych kosztów. Celem tej pracy jest podanie kilku praktycznych, istotnych wskazówek, które ułatwia konserwatorom samodzielne prawidłowe pobieranie próbek do badań mikroorganizmów, a także grzybów domowych, porostów, owadów i in.

\section{Próbki do badań mikrobiologicznych}

W zależności od celu i zakresu planowanych badań mikrobiologicznych zabytku można wybrać najodpowiedniejszą metodę spośród kilku możliwych (tab. 1). Ogólnie mówiąc, każda z metod polega na pobraniu warstwy biologicznej obecnej na powierzchni zabytku. W warstwie tej znajduja się komórki mikroorganizmów, zarówno żywe, jak i martwe, oraz produkty ich aktywności życiowej - śluzy, produkty rozkładu zabytkowego podłoża, np. fragmenty włókien, związki barwne, a także zabrudzenia, np. cząstki kurzu. Jeśli badania mają się ograniczyć do obserwacji mikroskopowych, można pobrać warstwę biologiczną z powierzchni na taśmę klejąca lub delikatnie ją zdjacć i przełożyć do pojemnika. Obserwacja mikroskopowa da nam odpowiedź na pytanie, czy za widoczne zniszczenie są odpowiedzialne drobnoustroje. Wstępnie można się też zorientować, jakie sa to drobnoustroje, tzn. bakterie, grzyby czy glony, i czy są one liczne. Jeśli jednak chcemy uzyskać więcej informacji, np. jakie rodzaje lub gatunki drobnoustrojów rosną na obiekcie, jakie mają uzdolnienia do niszczenia zabytkowego podłoża lub też ile ich przypada na jednostkę powierzchni obiektu, konieczne jest pobranie próbki do hodowli.

Przy wszelkich metodach pobierania należy zachować dużą ostrożność, tak aby nie uszkodzić podłoża lub warstw wykończeniowych, które zazwyczaj wskutek działania mikroorganizmów są osłabione i kruche. 
Tab. 1. Podział metod pobierania próbek ze względu na cel badania

\begin{tabular}{|c|l|l|}
\hline \multicolumn{2}{|c|}{ Planowane badanie mikrobiologiczne } & \multicolumn{1}{c|}{ Sposób pobrania } \\
\hline \multirow{2}{*}{ Badanie mikroskopowe } & Mikroskop świetlny & $\begin{array}{l}\text { odcisk na taśmę klejącą } \\
\text { zdjęcie warstwy biologicznej i przełożenie do czyste- } \\
\text { go pojemnika }\end{array}$ \\
\cline { 2 - 3 } & $\begin{array}{l}\text { Skaningowy mikroskop elektronowy } \\
\text { (SEM) }\end{array}$ & $\begin{array}{l}\text { pobranie niewielkiej próbki podłoża z warstwą bio- } \\
\text { logiczną }\end{array}$ \\
\hline Hodowla & $\begin{array}{l}\text { Identyfikacja gatunków niszczących, anali- } \\
\text { za ilościowa, inne badania }\end{array}$ & $\begin{array}{l}\text { zdjęcie warstwy biologicznej i przełożenie do jało- } \\
\text { wego pojemnika } \\
\text { odcisk na płytkę kontaktową }\end{array}$ \\
\hline Metoda bioluminometryczna & $\begin{array}{l}\text { Analiza ilościowa stopnia zanieczyszczenia } \\
\text { powierzchni przez żywe mikroorganizmy }\end{array}$ & $\begin{array}{l}\text { wymaz chemicznie czystą wymazówką testową } \\
\text { z określonej powierzchni }\end{array}$ \\
\hline
\end{tabular}

\section{Próbki do badań mikroskopowych}

Odcisk na taśmę klejącą. Przyklejanie warstwy biologicznej do taśmy klejącej jest metodą bardzo wygodną i dostarcza nam ogólnych informacji o obecności i rozmieszczeniu drobnoustrojów na badanej powierzchni. Przezroczystą taśmę klejąca delikatnie przykleja się do podłoża z warstwą biologiczna, lekko dociska w miejscu występowania mikroorganizmów, a następnie ostrożnie odkleja. Na taśmie pozostają mikroorganizmy z badanej warstwy biologicznej i ten fragment taśmy przykleja się do czystego szkiełka mikroskopowego podstawowego. Metodą tą można pobierać materiał biologiczny z różnych podłoży (papieru, skóry, płótna, ceramiki itp.), jednak zawsze należy zwrócić szczególną uwagę, aby przy odklejaniu taśmy z obiektu nie uszkodzić osłabionego zabytkowego podłoża lub warstw dekoracyjnych. W celu zminimalizowania tego zagrożenia fragment taśmy, na który pobieramy mikroorganizmy, może być niewielki, np. kwadrat o boku $5 \mathrm{~mm}$. Jeśli podłoże jest bardzo słabe i kruche, należy zaniechać tej metody. Z drugiej strony przy pobieraniu w ten sposób próbli z podłoża pokrytego grubą warstwa mikroorganizmów trzeba uważać, aby warstwa przyklejonych mikroorganizmów była na tyle cienka, żeby było możliwe ogląanie jej w świetle przechodzacym w mikroskopie świetlnym. W przeciwnym razie preparat będzie za gruby i zbyt kryjacy, co uniemożliwi obserwację mikroskopową. 
Badanie mikroskopowe pobranej w ten sposób próbki pozwala potwierdzić, czy zniszczenie jest pochodzenia mikrobiologicznego, oraz ustalić orientacyjnie, jakie mikroorganizmy są w nim obecne lub dominuja - grzyby, bakterie czy glony. Można też zaobserwować, czy kolonia grzyba składa się ze strzępek i zarodników, co świadczy o jej aktywnym rozwoju, czy obecne są tylko duże ilości zarodników. Określenie rodzaju mikroorganizmów dzięki tej metodzie jest możliwe jednak tylko w przypadku grzybów, które maja charakterystyczne zarodniki, takie jakie można zaobserwować np. u przedstawicieli rodzajów Alternaria, Cladosporium, Trichothecium. W badaniu mikroskopowym można stosować powiększenie 400x, ponieważ w powiększeniu 1000x ze względu na obecność taśmy klejącej trudno uzyskać ostry i czysty obraz (fot. 3 i 4). Materiał biologiczny najlepiej zbadać jak najszybciej po pobraniu, ale nawet po kilku tygodniach przechowywania go na szkiełku podstawowym i w woreczku strunowym nie zmienia on wyglądu w sposób istotny.

Zdejmowanie warstwy biologicznej. Jeśli próbka warstwy biologicznej zdjęta z obiektu ma być tylko zbadana pod mikroskopem, do jej przechowywania wystarczy czysty i nieużywany pojemnik, niekoniecznie jałowy. Z powodzeniem nadaja się do tego woreczki strunowe. Do pobierania można używać czystych skalpeli, pęset lub igieł preparacyjnych. Przy pobieraniu próbki należy koniecznie zwrócić uwagę, aby w miarę możliwości pobrać tylko warstwę biologiczna bez podłoża, które utrudnia obserwacje mikroskopowa.

\section{Pobieranie próbki do obserwacji w skaningowym mikroskopie} elektronowym (SEM). Rozmiary próbki do obserwacji w SEM nie moga być większe od średnicy stolika, do której się ją przykleja przed włożeniem do mikroskopu, czyli ok. $7 \mathrm{~mm}$. W praktyce stosuje się próbki niewielkie, nawet o wymiarach 1-2 mm. Ważne jest jednak, aby próbki się nie kruszyły, ponieważ materiał biologiczny w celu przygotowania do obserwacji w SEM powinien być utrwalany i odwadniany w szeregu roztworów. Dlatego w tym przypadku pobiera się nie samą warstwę biologiczną, ale także fragment podłoża. Daje to dodatkowe korzyści, ponieważ można ocenić nie tylko ilość i różnorodność mikroorganizmów, ale także stopień i rodzaj 
zniszczenia podłoża, np. włókien kolagenowych, celulozowych, powierzchni kamienia lub tynku (fot. 5).

\section{Próbki przeznaczone do hodowli mikroorganizmów}

Wyhodowanie mikroorganizmów odpowiedzialnych za zniszczenie zabytku nie jest łatwe z kilku powodów. Wiele z barwnych zaplamień widocznych np. na zabytkowym papierze powstało przed laty, kiedy obiekt był zawilgocony. W miarę, jak warunki przechowywania obiektu poprawiały się, kolonie drobnoustrojów zamierały. Najodporniejsze zarodniki wielu grzybów pleśniowych moga co prawda zachować zdolność kiełkowania przez kilkanaście lub nawet kilkadziesiąt lat, ale w końcu też zamierają i nie można ich przywrócić do życia w hodowli. W tab. 2 wymienione sa lata i miesiące, po jakich przynajmniej część komórek podanych drobnoustrojów, przechowywanych w warunkach laboratoryjnych, była jeszcze w stanie wykiełkować na świeżym podłożu².

Tab. 2. Czas przeżycia mikroorganizmów w warunkach laboratoryjnych (wg różnych autorów)

\begin{tabular}{|c|c|}
\hline Mikroorganizmy & Czas przeżycia \\
\hline Aspergillus fumigatus & $>15$ lat \\
Alternaria $s p$. & $>2$ lata 8 miesieccy \\
Chaetomium $s p$ & $>2$ lata 8 miesieccy \\
Trichoderma $s p$. & $>2$ lata 8 miesięcy \\
Mucor $s p$. & $8-10$ lat \\
Streptomyces $s p p$. & $28-30$ lat \\
Cladosporium cladosporioides & 1 rok \\
\hline
\end{tabular}

Inna przyczyną trudności związanych z hodowla jest fakt, że ze środowisk naturalnych udaje się wyhodować zaledwie niewielki ułamek występujących tam drobnoustrojów, np. z gleby tylko 1\%. Szacuje się, że

2 A. S. Sussman, Longevity and survavibility of fungi, [w:] The Fungi: An Advanced Treatise, Vol. II. The Fungal Population, Eds. G. C. Ainsworth and A.S. Sussman, Academic Press, New York 1966, s. 477-486, za: M.-L. Florian., Heritage Eaters, James \& James (Science Publishers) Ltd., London 1997; A. Taddei, M. Milagros Tremarias, C. Hartung de Capriles, Viability studies on actinomycetes, "Mycopathologia" 143, s. 161-164, 1999; Karbowska-Berent, dane niepubl. 
obecnie znanych jest zaledwie 5\% grzybów i 12\% bakterii występujących w środowisku naturalnym ${ }^{3}$. Aktualnie nie są dostępne dane, jaki ułamek drobnoustrojów można wyhodować ze zniszczonych zabytków. Pozostałe mikroorganizmy, których jest większość, nie rosną w warunkach hodowlanych mimo starań, aby warunki te były jak najbardziej zbliżone do naturalnych. Ich wykrycie i identyfikacja są możliwe tylko za pomocą nowoczesnych technik biologii molekularnej.

Przy pobieraniu próbek z obiektów zabytkowych pojawia się jeszcze inna trudność, szczególnie jeśli pobiera się próbkę warstwy biologicznej z powierzchni malowideł ściennych lub innych obiektów, które przez lata ulegały zabrudzeniu przez tzw. pył osiadły, czyli kurz. Oprócz drobnoustrojów odpowiedzialnych za zniszczenie zabytku na jego powierzchni znajduja się wskutek tego zawsze pewne ilości zarodników grzybów lub przetrwalników bakterii, które opadły wraz z pyłem z powietrza i współtworzą warstwę kurzu. Zdarza się często, że właśnie te „przypadkowe” mikroorganizmy wyrastaja w hodowli szybciej, sa mniej wymagające i „zagłuszaja” wzrost drobnoustrojów odpowiedzialnych za zniszczenia. W przypadku silnie zakurzonych powierzchni, np. malowideł ściennych, zaleca się nawet ich wstępne odkurzenie, tak aby do badań pobierać tylko mikroorganizmy niszczące malowidło. Samo pobieranie próbek mikrobiologicznych do hodowli należy przeprowadzać w miarę możliwości sterylnie, aby uniknąć zanieczyszczenia mikroorganizmami z pyłu osiadłego.

Zdejmowanie warstwy biologicznej do hodowli. Podstawowym wymogiem obwiązującym przy zdejmowaniu warstwy biologicznej do hodowli jest zachowanie sterylności podczas pobierania próbek. Aby narzędzia do pobierania próbki, takie jak skalpel, pęseta lub igła preparacyjna, były jałowe, należy ich końcówki, które będą się stykały z próbka, przez chwilę opalić w płomieniu palnika. Następnie wystudzonym narzędziem należy pobrać próbkę i przełożyć ją do jałowego pojemnika. Można w tym celu użyć pojemnika do badania moczu na posiew lub koperty z folii aluminiowej przetartej etanolem i opalonej w płomieniu palnika. Płomień, który

3 M. Frąc, S. Jezierska-Tys, Różnorodnośc mikeroorganiẓmów środowiska glebowego, „Postępy Mikrobiologii" 40, 2010, s. 47-58. 
przez chwilę obejmie przetartą etanolem powierzchnię, spowoduje śmierć wszystkich obecnych na niej drobnoustrojów. Nie może być takim pojemnikiem kartka papieru wydarta $z$ notesu ani fiolka po filmie fotograficznym. Nawet woreczki strunowe nie są przydatne, jeśli chcemy materiał z próbli hodować, ponieważ nie są jałowe.

Tak zamkniętych próbek z drobnoustrojami nie należy przechowywać dłużej niż 2-3 dni, ponieważ dłuższe przechowywanie powoduje zamieranie niektórych drobnoustrojów, co będzie zmniejszało wiarygodność uzyskanych wyników. Próbki należy przez ten czas przechowywać w lodówce lub na czas transportu w turystycznej torbie termosowej, zdolnej do utrzymania temperatury ok. $4^{\circ} \mathrm{C}$.

Prawidłowo pobrana próbka pozwala na wysianie materiału biologicznego na odpowiednio dobrane pożywki hodowlane, osobne dla grzybów, dla bakterii i dla promieniowców, oraz selektywne, zbliżone jak najbardziej składem do podłoża, na którym żyły mikroorganizmy. Hodowle powinny być inkubowane w temperaturze zbliżonej do tej, w której przebywał badany obiekt. Metody hodowlane pozwalają na wyizolowanie czystych kultur mikroorganizmów, a następnie na ich identyfikację i badania właściwości (fot. 6). Jeśli próbkę pobrano z fragmentu obiektu o znanych rozmiarach powierzchni, np. z powierzchni kwadratu o boku 5 x $5 \mathrm{~cm}$, dzięki metodom hodowlanym można określić liczebność mikroorganizmów w przeliczeniu na jednostkę powierzchni. Jest to szczególnie przydatne do różnego rodzaju porównań, np. przed i po dezynfekcji, próbki z różnych miejsc w tym samym obiekcie itp. Hodowle wymagaja jednak dość dużo czasu - na wzrost grzybów w temperaturze pokojowej czeka się co najmniej 5-7 dni od zaszczepienia, na wzrost promieniowców ok. dwa tygodnie, jedynie większość kolonii bakterii pojawia się już po jednej lub dwóch dobach. Jeszcze więcej czasu wymaga otrzymanie czystych kultur i ich identyfikacja.

Odcisk na płytkę kontaktową. Ten sposób pobierania materiału biologicznego umożliwia przeniesienie drobnoustrojów z badanej powierzchni bezpośrednio na pożywkę hodowlaną o odpowiednim składzie. Powierzchnia zastygłej pożywki znajduje się nieco powyżej krawędzi płytki, które dzięki temu nie przeszkadzaja w kontakcie zabytkowego podłoża z pożywką. W momencie przyłożenia płytki kontaktowej do zniszczonej powierzchni 
zabytku drobnoustroje przyklejają się do pożywki i na niej pozostają. Płytki z pobranym materiałem można następnie przechować w torbie termosowej i jak najszybciej dostarczyć do laboratorium lub umieścić w szczelnym pojemniku plastikowym i inkubować w pobliżu badanego obiektu przez co najmniej tydzień. Metoda ta daje efekty podobne jak metoda wysiewu materiału biologicznego, a dodatkowo informuje orientacyjnie o rozmieszczeniu i liczebności mikroorganizmów (fot. 7). Gotowe płytki kontaktowe sa dostępne w firmach oferujących odczynniki i materiały dla mikrobiologii. Można również zakupić puste płytki kontaktowe, które napełnia się odpowiednio dobraną pożywką w laboratorium ${ }^{4}$.

\section{Metoda bioluminometryczna}

Metoda bioluminometryczna polega na oznaczaniu poziomu związku obecnego we wszystkich żywych komórkach - adenozyno-5-trifosforanu (ATP) - i należy do grupy metod badania mikroorganizmów bez konieczności ich hodowli. Funkcja ATP w komórkach polega na magazynowaniu energii i dostarczaniu jej do procesów życiowych zachodzacych w organizmach. Po śmierci komórki cząsteczki ATP szybko ulegaja autolizie, dlatego metoda ta nadaje się do określania stopnia zanieczyszczenia powierzchni przez żywe mikroorganizmy. Co prawda, wyniku uzyskanego tą metoda nie można bezpośrednio przełożyć na liczebność mikroorganizmów, ponieważ komórki różnych gatunków maja niejednakowe ilości ATP, niemniej jednak metoda bioluminometryczna daje o wiele lepszą orientację co do liczebności żywych drobnoustrojów niż metoda odcisku na płytki kontaktowe i to po zaledwie kilku minutach. Jest ona stosowana głównie w przemyśle spożywczym ${ }^{5}$, ale ostatnio znajduje też zastosowanie w badaniach zabytków ${ }^{6}$.

\footnotetext{
4 D. Kołożyn-Krajewska (red.), Higiena produkecji żymności, Warszawa 2003.

5 K. Czaczyk, Bioluminescencyjny pomiar ATP - szybka metoda oceny zakażenia mikrobiologicznego, „Przemysł Spożywczy” 12/1999, s. 39-41; Z. Żakowska, H. Stobińska, Mikrobiologia $i$ higiena w pržemyśle spośzwożym, Łódź 2000.

${ }_{6}$ M. Rakotonirainy, J. Hanus, S. Bonssies-Termes, C. Heraud, B. Lavedrine, Detection of Fungi and Control of Disinfections by ATP-Bioluminescence assay, $5^{\text {th }}$ International Conference on Biodeterioration of Cultural Property, 2003, s. 25-32; J. Karbowska-Berent, I. Kotala, Biolu-
} 
Wykonanie tego badania obejmuje pobranie próbki jałową wymazówką umieszczenie jej w specjalnej, kilkuczęściowej probówce testowej oraz pomiar ATP w próbce za pomocą bioluminometru? ${ }^{7}$ Pierwsze dwie czynności może przeprowadzić sam konserwator po krótkim instruktażu. Wymazówkę zanurza się w sterylnej i chemicznie czystej wodzie, której zbiorniczek znajduje się w górnej części probówki testowej. Nadmiar wody należy odcisnąc na ściance zbiorniczka i nawilżoną wymazówką przetrzeć równomiernie badana powierzchnię zabytku, np. kwadrat o boku $3 \mathrm{~cm}$, tak aby zebrać z niej jak najwięcej mikroorganizmów. Dla ułatwienia obszar pobierania materiału biologicznego powinien być ograniczony szablonem, najlepiej metalowym, żeby można go było wysterylizować przez opalenie. Następnie wymazówkę z drobnoustrojami wkłada się jeszcze raz do wody w górnej części probówki testowej i staranie wytrząsa, tak aby mikroorganizmy zostały w wodzie. Powstałą zawiesinę trzeba mocno wstrząsnąć, aby była jednorodna, po czym zanurza się w niej zawartą w probówce testowej krótką pipetkę, która pobiera ilość zawiesiny potrzebną do reakcji. Górną część probówki testowej i wymazówkę wyrzuca się, a pipetkę należy wcisnąc do dolnej części testu. Na tym etapie test może być w lodówce przechowywany do 48 godzin, zanim zostanie dostarczony do laboratorium, gdzie będzie zbadany poziom ATP w bioluminometrze.

Na ogół poziom ATP nieprzekraczający 500 RLU na powierzchni kwadratu o boku $3 \mathrm{~cm}$ można przyjąć jako niski i spowodowany przez drobnoustroje z powietrza i kurz. Jednak każdy obiekt powinno traktować się indywidualnie i dlatego istotne jest porównanie poziomu ATP z tzw. tła, czyli z miejsca na tym samym obiekcie, ale wolnego od widocznych nieuzbrojonym okiem objawów zniszczeń. Jeśli poziom ATP w miejscu dotkniętym atakiem drobnoustrojów pięciokrotnie przekracza poziom tła, na ogół przyjmuje się, że skażenie żywymi drobnoustrojami w miejscu zaatakowanym jest znaczne i należy rozważyć potrzebę dezynfekcji obiektu.

minescencja - szyblea metoda wykrywania synych drobnoustrojów na powierzchniach zabytków - wyniki wstępnych badań, „Biuletyn Informacyjny Konserwatorów Dzieł Sztuki” 17, 2006, s. 64-65.

Badanie można wykonać m.in. w Zakładzie Konserwacji Papieru i Skóry w Instytucie Zabytkoznawstwa i Konserwatorstwa UMK w Toruniu. 


\section{Pobieranie próbek w celu identyfikacji grzybów domowych}

Nazwa „grzyby domowe” obejmuje podstawczaki niszczące drewno w budynkach, takie jak stroczek łzawy, grzyb piwniczny, grzyb domowy biały i inne. Grzyby te rozróżnia się na podstawie ich cech makroskopowych, tj. budowy, wielkości, kształtu i koloru owocników, sznurów i grzybni (fot. 8). Pod mikroskopem bada się najczęściej zarodniki tych grzybów, rzadziej grzybnię. Do identyfikacji grzybów z tej grupy niezbędna jest dokumentacja fotograficzna oraz w miarę możliwości próbka drewna lub muru pokryta sznurami, same sznury, ewentualnie owocnik lub jego fragment. W przypadku rzadziej spotykanych grzybów niszczących drewno konieczne są oględziny specjalisty.

\section{Pobieranie próbek w celu identyfikacji porostów i mchów}

$\mathrm{Na}$ obiektach kamiennych, z betonu, cegły lub na tynku, wyeksponowanych na działanie warunków atmosferycznych i światła słonecznego, bardzo często są widoczne zielonkawe, żółte lub szare plechy porostów (fot. 9). Ich identyfikacja wymaga zdjęcia plech z powierzchni zabytku i dostarczenia do pracowni lichenologa. Najlepiej jeśli plecha jest pobrana w całości, a jeśli próbka rozpada się, należy w miarę możliwości pobrać ją razem z powierzchniową warstwa podłoża. Próbkę należy umieścić w czystym, choć niekoniecznie jałowym pojemniku. Można ja przechowywać przez wiele miesięcy. Podobne zasady obowiązuja przy zdejmowaniu warstwy mszaków z powierzchni zabytku. Identyfikacja mszaków zajmuje się briolog.

Dla lichenologa i briologa istotne sa ponadto informacje o rodzaju podłoża, na jakim rosły porosty i mchy, a także o tym, z jakiej okolicy próbka pochodzi (kraj, miejscowość), kiedy została pobrana (przynajmniej w jakim miesiącu), z jakiej strony obiektu (z południowej, zachodniej itd.) oraz na jakiej wysokości od gruntu. 


\section{Pobieranie próbek z żerowisk owadów}

Dokładna identyfikacja gatunków owadów, które niszczą zabytek, jest potrzebna przy wyborze metody dezynsekcji, szczególnie jeśli planuje się zastosowanie specyficznych gatunkowo pułapek feromonowych. Do identyfikacji owadów odpowiedzialnych za zniszczenia obiektów zabytkowych najlepiej nadają się formy doskonałe chrząszczy. U chrząszczy niszczących drewno, np. u kołatka domowego i spuszczela pospolitego, okres tzw. rójki, czyli czas, kiedy z drewna wylatuja postacie doskonałe i odbywają lot godowy, przypada na późną wiosnę lub lato. Po 1-2 tygodniach od opuszczenia drewna chrząszcze gina, a ich szczątki można znaleźć w różnych zakamarkach, przede wszystkim na parapetach okiennych i gzymsach.

W książkach zniszczonych przez owady znalezienie ich szczątków, wylinek larwalnych, a niekiedy nawet żywych larw jest łatwiejsze niż w zabytkach z drewna. Wszelkie znalezione między kartami pozostałości należy zebrać do czystego pojemnika i dostarczyć do specjalisty. Identyfikacja owadów na podstawie cech morfologicznych larw lub wylinek jest dużo trudniejsza i wymaga gruntownej wiedzy entomologicznej.

Wiele cech przydatnych do oznaczenia gatunku owada, który zniszczył zabytek, można odkryć, obserwując pozostawione żerowisko i objawy zniszczenia (fot. 10). Istotne sa kształt i wielkość otworów wylotowych, szerokość korytarzy, gatunek i wiek drewna oraz kształt i wielkość odchodów larw w proszku drzewnym wysypującym się ze zniszczonego zabytku. Dlatego do identyfikacji owada konieczna jest dokumentacja fotograficzna żerowiska z dołączoną skalą, a także próbka proszku drzewnego pobrana do czystego pojemnika.

\section{Podsumowanie}

Przedstawiony przegląd metod pobierania próbek ogranicza się do praktycznych i prostych metod, z których moga skorzystać sami konserwatorzy, pozostawiając specjalistom z różnych dziedzin biologii dalsze badania. Dobrze jest połączyć dwie metody, np. przy pobieraniu mikroorganizmów odcisk na taśmę i badanie ATP, pozwoli to bowiem na pełniejszą ocenę 
zagrożenia zabytku przez mikroorganizmy. Dołączenie dokumentacji fotograficznej, tj. fotografii całego obiektu oraz miejsc zniszczonych z zaznaczeniem miejsc pobrania, znacząco ułatwia ocenę zagrożenia, ponieważ pokazuje obraz zniszczenia widoczny nieuzbrojonym okiem lub w niewielkim powiększeniu. Miejsca pobrania próbek powinny być także zaznaczone na rysunkach inwentaryzacyjnych obiektów.

\section{Podziękowania}

Serdecznie dziękuję pp. prof. dr Bogumile Rouba, dr hab. Elżbiecie Jabłońskiej, prof. UMK, dr hab. Jadwidze Lukaszewicz, prof. UMK, a także mgr Marii Rudy i mgr Joannie Jarmiłko za krytyczne i życzliwe uwagi do niniejszego tekstu.

\section{Summary}

\section{Methods of sampling for the biological research of cultural heritage}

In the conservatory practice historic items deteriorated by microorganisms moulds, bacteria, aerophilic algae - and higher organisms - wood-destroying fungi, insects, lichens and mosses - are encountered quite frequently. Properly taken samples are then necessary to estimate the vitality of microorganisms, to identify the species of the organisms causing biodeterioration and to choose the optimal combating method. Only the properly taken samples are useful to the research made by specialists in various fields of biology. The sampling conducted by a conservator and a biologist together is not always possible, therefore this work presents some instructions for conservators facilitating them the unassisted appropriate sampling of microorganisms as well as wood-destroying fungi, lichens, mosses and insects. The rules concerning the sampling of biofilm to the microbiological research are discussed, including methods aiming for the culturing and identification of microorganisms. The methods of sampling for other investigation of the microorganisms are also presented, namely the print on transparent Scotch tape, sampling to the SEM observation and bioluminescence assay owing to which the estimation of contamination a surface by living microorganisms is possible. Moreover, the instructions for the proper sampling of wood-destroying fungi as well lichens, mosses and insects are discussed. The special attention is paid to the caution required during the sampling to avoid any further destructions of the historic support weakened by the activity of the deteriorating organisms. 


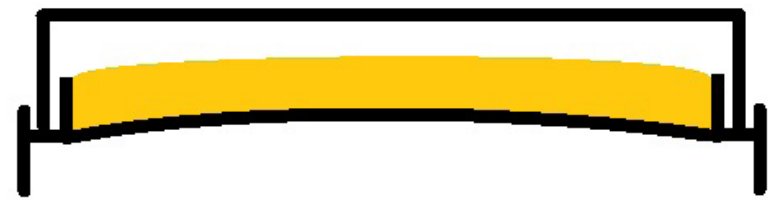

Ryc. 1. Schemat płytki kontaktowej

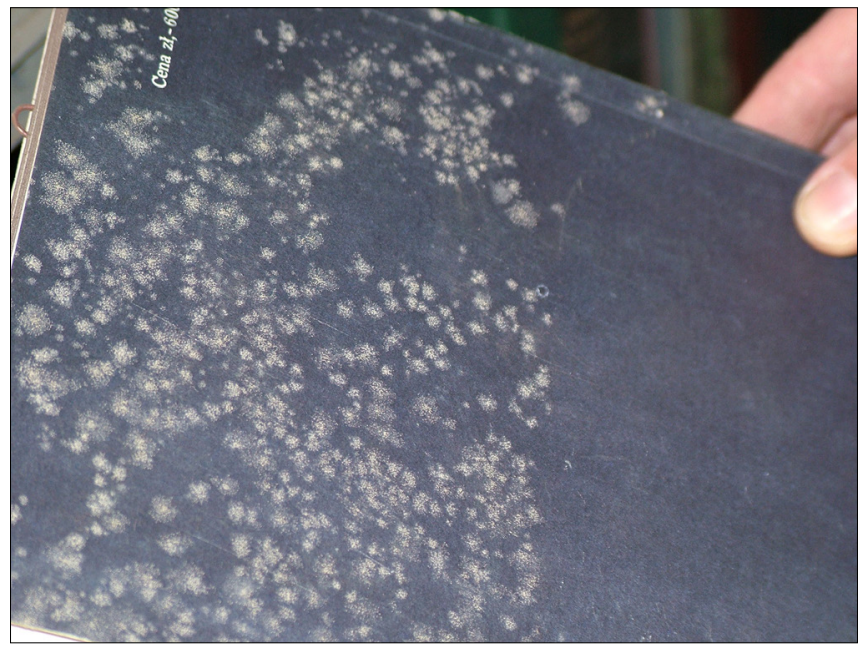

Fot. 1. Kolonie grzybów pleśniowych na oprawie książki (fot. H. Rosa)

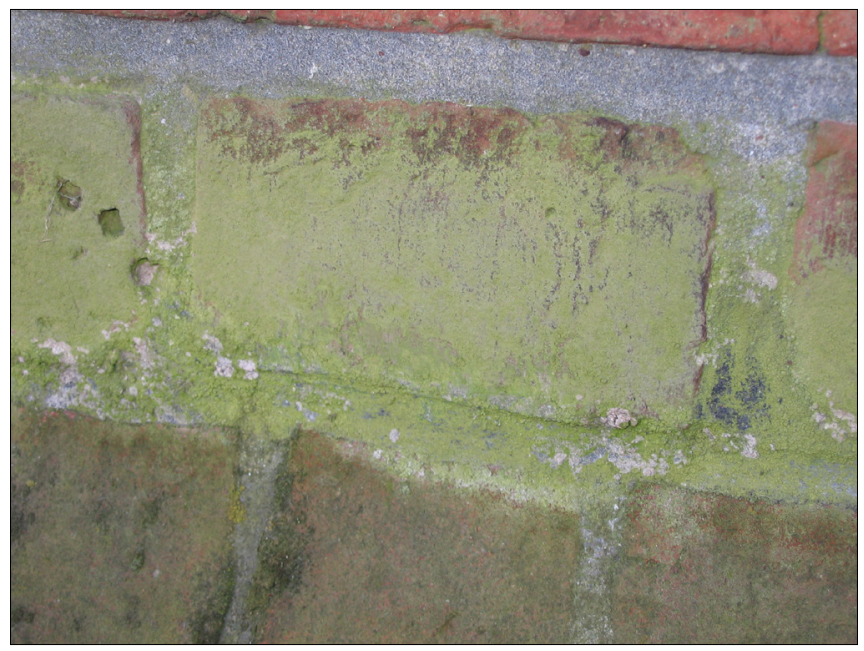

Fot. 2. Zielona warstwa glonów aerofilnych na powierzchni cegieł i zaprawy (fot. J. Lukaszewicz) 


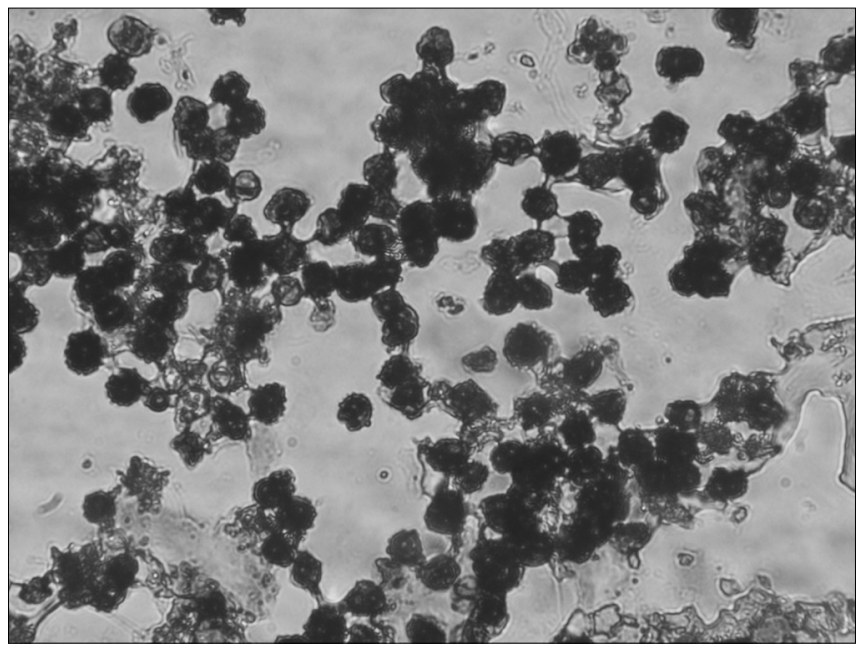

Fot. 3. Konidia Trichocladium asperum (próbka pobrana na taśmę klejąca ze ściany w zabytkowej willi), x 400 (fot. J. Karbowska-Berent)

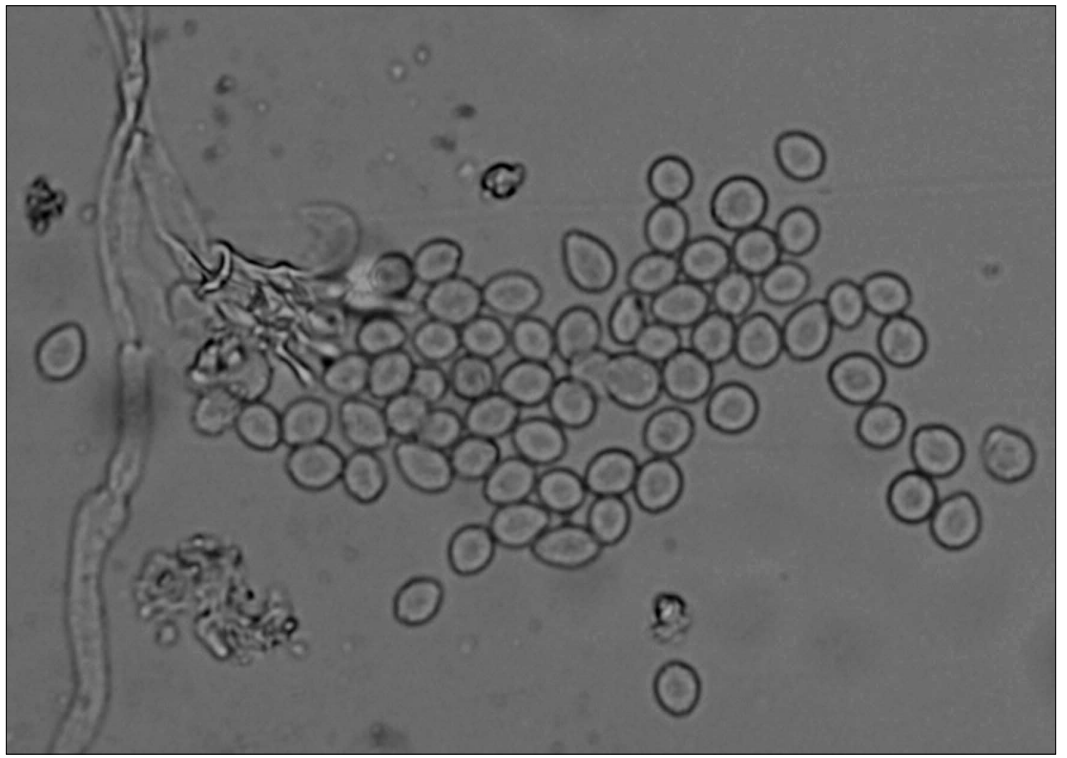

Fot. 4. Aparat konidialny Scopulariopsis brevicaulis (próbka pobrana na taśmę klejącą z oprawy książkowej), x 400 (fot. J. Karbowska-Berent) 


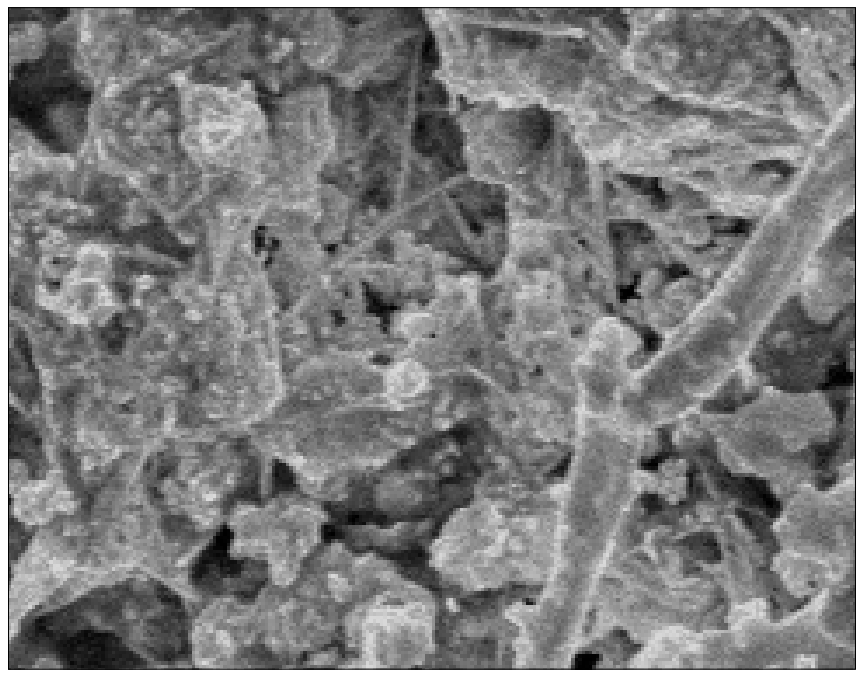

Fot. 5. Strzępki grzybni na powierzchni malowidła ściennego widoczne w SEM (fot. J. Karbowska-Berent)

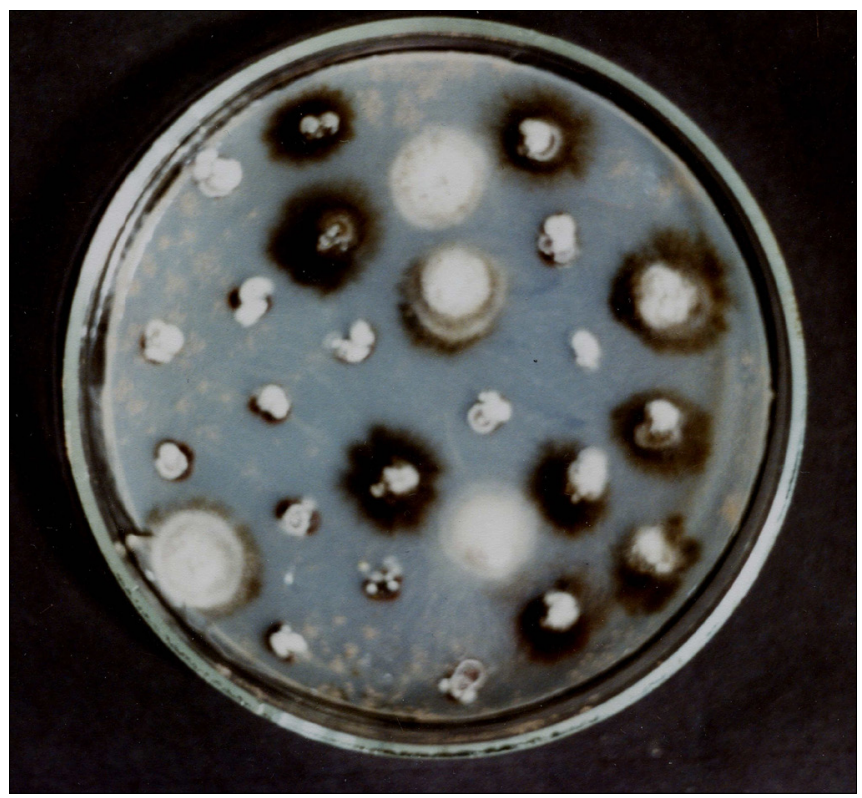

Fot. 6. Kolonie mikroorganizmów uzyskane metodą wysiewu punktowego minimalnych ilości materiału biologicznego na pożywkę hodowlaną. Próbka pobrana z malowidła ściennego pokrytego białymi nalotami (fot. J. Karbowska-Berent) 


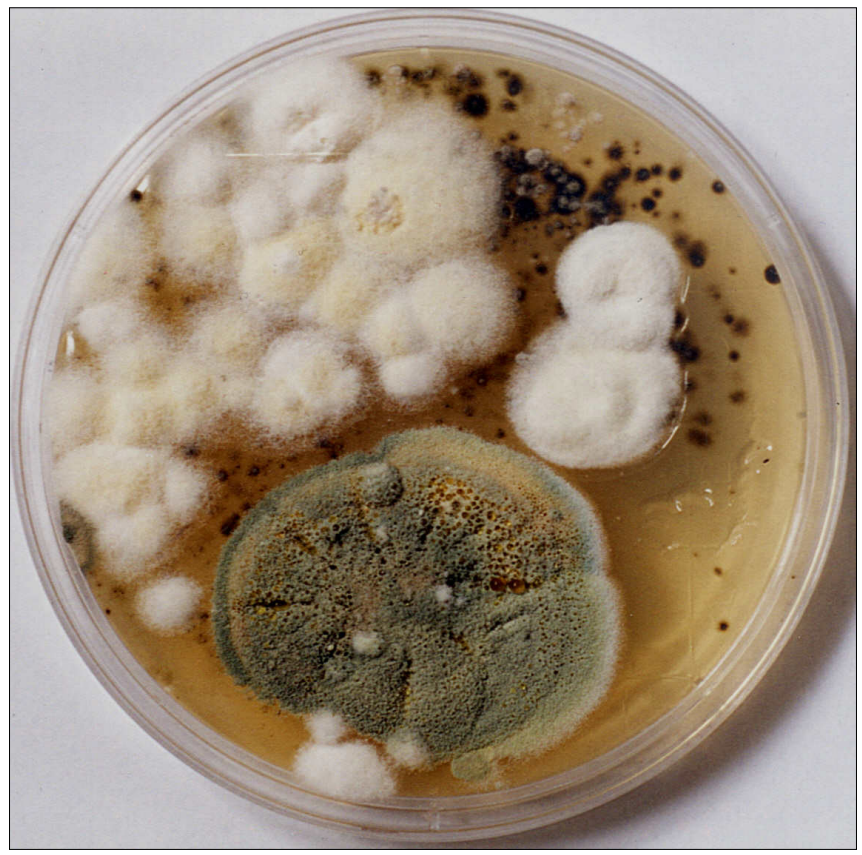

Fot. 7. Kolonie grzybów pleśniowych na płytce kontaktowej po 7-dniowej inkubacji. Próbka pobrana z malowidła ściennego pokrytego białymi nalotami (fot. J. Karbowska-Berent)

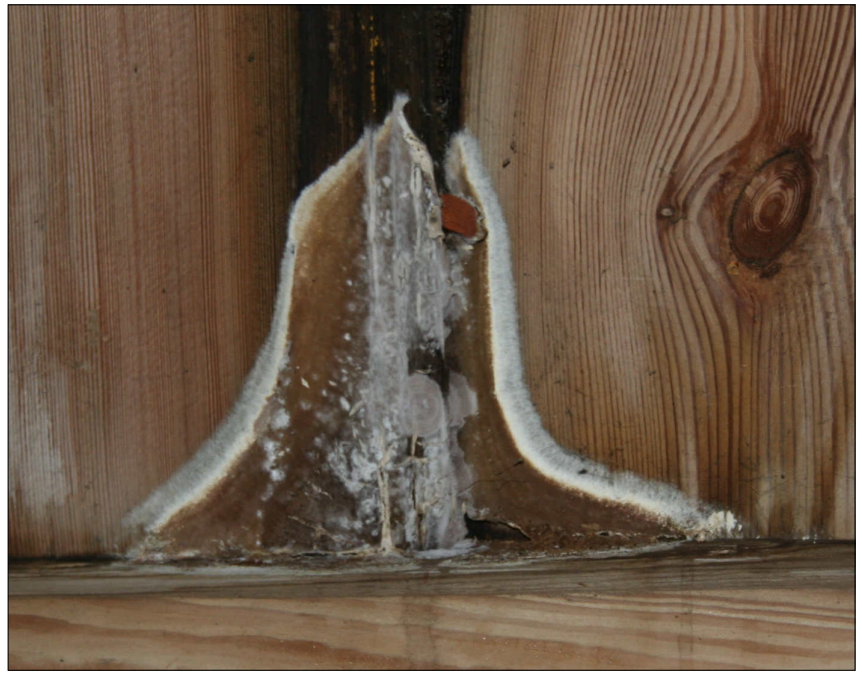

Fot. 8. Owocnik stroczka łzawego na drewnianej ścianie (fot. K. Polak) 


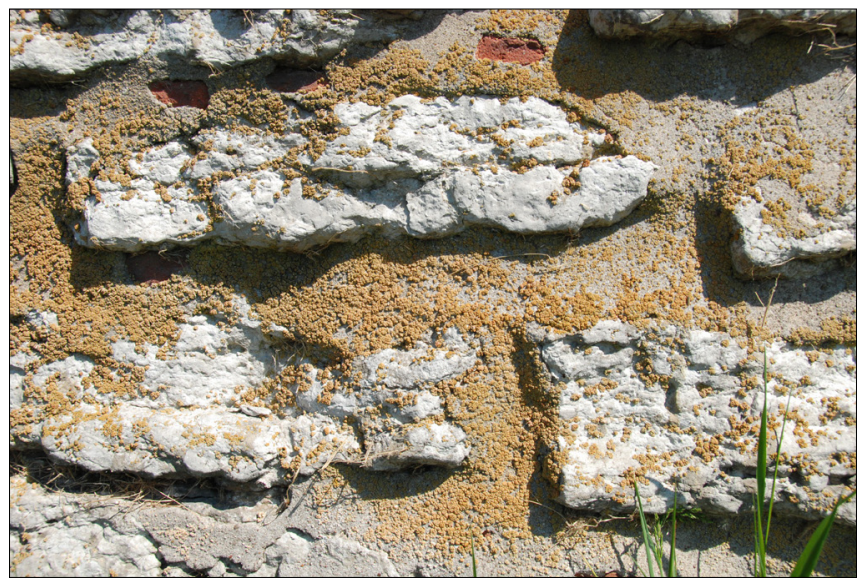

Fot. 9. Pomarańczowożółte porosty na zaprawie i kamieniu (fot. J. Karbowska-Berent)

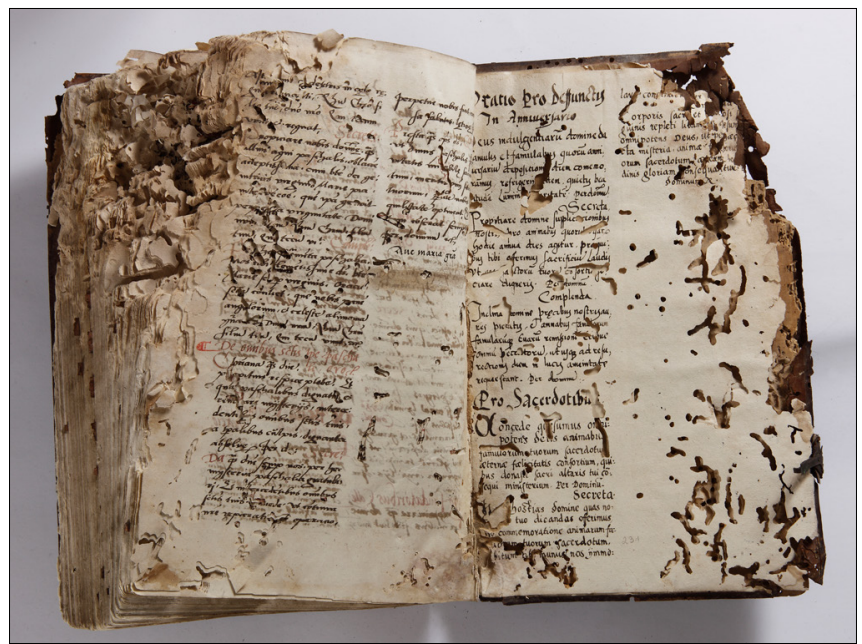

Fot. 10. Żerowisko tykotka pstrego w „Missale Speciale ...”, 1521, Bazylea, własność Archiwum Archidiecezjalnego w Gnieźnie; konserwacja-restauracja $\mathrm{w}$ ramach pracy dyplomowej wykonywanej przez A. Dymarek pod kierunkiem dr Małgorzaty Pronobis-Gajdzis w Zakładzie Konserwacji Papieru i Skóry UMK w Toruniu (fot. A. Dymarek) 